\title{
12
}

\section{New Zealand and Australia in Pacific Regionalism}

\section{Nicola Baker}

Much of the current debate about the future of the Pacific regional architecture revolves around the appropriate level of engagement for Australia and New Zealand. Because they are both developed country members of the most prominent regional forum, whose presence has created some problems for their developing country counterparts, and who have contributed to the formation of other regional and sub-regional groupings, it is understandable that they are now being discussed as a single unit. They are in the same awkward position of being major aid donors to the other members of the Pacific Islands Forum, of having the resources and capacity to dominate regional meetings, and of being a hindrance to the forum's credibility and utility as a vehicle for southsouth cooperation.

But is it otherwise useful to refer to 'Australia and New Zealand' as if they were umbilical twins, as analysts of regional international relations have long tended to do? Or to assume that Australia always leads and New Zealand follows, as this invariable ordering suggests? Is it simply a matter of contrasting approaches, as inferred by the common allusions to their playing 'bad cop' and 'good cop', or could it be that they have different interests in, and perspectives on, Pacific regionalism? 
This chapter discusses New Zealand's role in the regionalism of the independent Pacific from the 1960s until the early 21 st century. It finds that New Zealand has long had a unique sense of identification with the region, and that its interest and activity in regional matters has been enduring and intense, and that it has - usually but not always - been sensitive to Pacific Island concerns and desires. This has been based on its own calculations of what the region requires and it has tried to persuade other powers with an interest, including Australia, to behave in ways that accord with those calculations.

Perhaps the most overlooked aspect of New Zealand's engagement in the regionalism of the independent Pacific is that it has had a longer history of interest and activism than Australia. Forging ahead with the decolonisation of its territories, concerned about French nuclear testing, and impatient with the 'pottering' of the Australian initiated South Pacific Commission, New Zealand's Department of External Affairs (DEA) had by the mid-1960s begun rethinking the merits of the existing regional framework. ${ }^{1}$ In 1961, Deputy Secretary Frank Corner had suggested that a revitalisation of the South Pacific Commission might suffice, but by 1967 he and his colleagues had begun considering the option of a completely new forum, to be composed of independent island states. They told their metropolitan counterparts (excluding France) in that year's four-power talks on the future of the Pacific that this forum 'should ideally be a grouping of indigenous governments', with Western Samoa, Tonga, and Fiji possibly forming the founding group. New Zealand warned that 'although there would be a need for metropolitan guidance, it would be best for the guidance to be inconspicuous'. ${ }^{2}$

The Australian delegation thought this idea a good one, but with national attention focused on Southeast Asia, and with changes in government, ministers and department heads, it appears to have slipped from the institutional memory. Australia did not begin giving serious consideration to the formation of a new regional organisation until April 1970, when Albert Henry, Premier of the Cook Islands, mentioned the idea on a visit to Department of Foreign Affairs (DFA) officials in Canberra. Australia wrongly took Henry's suggestions for change in the existing regional architecture to be tentative, and began thinking about ways in which Australia might encourage the establishment of a new regional grouping (Doran 2004). As DFA refined its thinking and its proposal wended its laborious way up to cabinet, officials grew increasingly suspicious that

\footnotetext{
1 New Zealand had been the only metropolitan power with territories in the South Pacific to vote in favour of the 1960 United Nations Declaration on the Granting of Independence to Colonial Countries and Peoples, had granted Samoa independence in 1962, and was working towards a change of status for the Cook Islands. 2 UK Public Records Office, FCO 32/343, 'Pacific Island Talks': Commonwealth Office notes on four-power talks in Washington, April 1967. Cited in Lal (2006).
} 
'New Zealand thinking (and perhaps action) may be further advanced than ours' ${ }^{3}$ New Zealand would admit only that 'the idea for a forum had germinated slowly during the last two years' ${ }^{4}$

New Zealand's early interest in the formation of a new regional organisation was driven in part by a realisation by the DEA that the country's foreign policy needed a focus that made more sense domestically and internationally. It was already imbued by a commitment to liberal internationalism, a commitment that has maintained almost uninterrupted bipartisan agreement to this day. But it had no geographic centre and was subject to the shifting interests of its allies and partners, on whom New Zealand then relied for an ultimate security guarantee and trade. The DEA official most concerned about this was Frank Corner, who had in 1951 voiced his unease in a letter about the negotiations on the formation of the Australia, New Zealand, United States Security Treaty (ANZUS) to his departmental secretary:

My mind still finds it difficult to reconcile the arrangements we are making An agreement for the Pacific, but commitment in reality in an area of the M[iddle] E[east] where we have no representation and no intelligence of our own; its all so untidy and I feel we are losing control of our own fate ... I have the feeling that we [are] getting into a curious colonial status (cited in McGibbon 1999, pp. 78-79).

Corner went public with his proposed solution ten years later, giving a passionate speech arguing that the South Pacific should become New Zealand's primary area of foreign policy interest and activity. He began by recalling Prime Minister Richard Seddon's 19th-century attempt to bring into being a Pacific federation, claiming that in doing so he had displayed 'a solid knowledge of New Zealand's interests and a sound feeling for New Zealand's geographical position'. He went on to call for a return to a focus on the South Pacific, arguing that, 'if we do not accept the implications of our geographic and historical situation and of the dual racial origin of our people, our foreign policy can not be fully realistic, consistent or effective'. ${ }^{5}$

All of Corner's arguments were cited and amplified by Professor Kenneth Cumberland in a public lecture delivered later in 1961 (and attended by the future Prime Minister of Fiji, Ratu Mara). He criticised the South Pacific

\footnotetext{
3 National Archives of Australia, A1838, 277/1/1/PART 1, A. J. Eastman, Memo to Secretary Department of External Affairs, 'Political Forum in the South Pacific', 23 November 1970.

4 UK Public Records Office, FCO 32/795/083, 'Political Forum in the Pacific', Letter to Pacific Dependent Territories Department from British High Commission, Wellington, 31 May 1971.

5 Archives New Zealand, R22848844, folio 101, F. H. Corner, 'New Zealand and the South Pacific', Speech at the Convention of the New Zealand Institute of Public Administration, 1961.
} 
Commission and its avoidance of 'crucial political, social and economic matters' and emphasised New Zealand's particular claim to a leading place in regional affairs by differentiating it from Australia:

Asia may be Australia's 'Near North'. The Pacific Ocean is ours. The interests of Australia and New Zealand are by no means identical. Our environment is the 'surrounding Pacific'. In the 'surrounding Pacific' New Zealand clearly has a unique role to play (Cumberland 1962, p. 391).

In 1971, DEA officials helped island leaders persuade Prime Minister Keith Holyoake to host the first meeting of what would become the South Pacific Forum. In 1972, Frank Corner was promoted to Secretary of External Affairs (and the Prime Minister's Department) and he and the like-minded Norman Kirk, who replaced Holyoake in the same year, were able to make a concerted push to marry the different strands of what Corner saw as New Zealand's unique foreign policy identity: its place in the Pacific, its liberal internationalism, and its commitment to global disarmament. New Zealand began openly assuming its 'unique role' in regional affairs, proposing and gaining island support for the establishment of the forum secretariat, the forum declaration on the Law of the Sea, and the first attempt at a South Pacific Nuclear Weapons Free Zone (Doran 2004, p. 18; WikiLeaks 1976).

These early initiatives were not popular with Australia, with the exception of the forum declaration on the Law of the Sea. Australia did not take any sustained interest in the affairs of the forum in these years, rousing itself only to oppose New Zealand's push for a regional nuclear-free zone when the United States made its concerns known to Gough Whitlam.

The election of the Hawke Labor Government in 1983 ushered in the first period of Australian activism in Pacific regionalism since 1944. Bob Hawke proposed a modified nuclear weapons-free zone and pushed for a regional ban on drift-net fishing. His successor, Paul Keating, maintained this high profile on environmental issues and it was he and his Minister for Pacific Island Affairs, Gordon Bilney, who insisted that improved economic governance become a regional objective. ${ }^{6}$

During this period, New Zealand was prepared to work with Australia on initiatives that it supported, such as the ban on drift-net fishing and the revival of the nuclear-free zone concept. But it did not always cooperate or even consult. New Zealand was not initially enthusiastic about the Australian government's

6 Greg Fry has produced the best analyses of Australia's role in Pacific regionalism over the years. See Fry (1997) for a detailed explanation and critique of the Keating Government's focus on regional economic governance. 
attempts to push island countries towards economic reform and did not keep Australia fully informed of its Bougainville conflict resolution initiatives (Brown 1997).

It was the Bougainville crisis that really gave birth to the notion of New Zealand playing 'good cop' to Australia's 'bad cop' in the region. Australia was unable to play a mediation role because of its open support for the Papua New Guinea government's position and its indirect support of the Papua New Guinea Defence Force's campaign against the rebels. As the neutral regional power, New Zealand was much more acceptable to the Bougainvilleans as a facilitator of peace negotiations and as leader of the first truce monitoring team. But the characterisation of New Zealand as 'good cop' in the Bougainville crisis implies a strategy agreed with the 'bad cop', and this was not the case as Australia's complaints about lack of consultation demonstrate.

The Bougainville experience did reveal something important about New Zealand's attitude towards cooperation with Australia and that is the significance of economic considerations, both bilateral and regional. With deepening integration into the larger Australian economy being a key New Zealand objective since the 1970s, its governments have increasingly recognised that there are 'straight commercial grounds' for getting their 'thinking clear on all issues that might affect the trans-Tasman relationship'. ${ }^{7}$ The consequences of its unilateral diplomacy on Bougainville drove home the regional importance of cooperation with Australia. New Zealand was unable to fund or man a longterm peace monitoring presence and had to turn these duties over to a betterresourced Australia. Since then, New Zealand has adopted a more consultative approach in recognition of the fact that it needs both Australia's financial support for regional initiatives and its contributions to regional assistance missions.

Australia's interest in the region waned again after the 1996 elections. The new Liberal Party government of John Howard was not much interested in what was happening in the region or in the South Pacific Forum, which he rarely attended. Until 2003, his government's regional interests did not extend much beyond ensuring that forum communiqués on matters such as climate change did not conflict with Australia's national interests. It was left to the New Zealand governments of Bolger, Shipley, and Clark and their island counterparts to push ahead on coordination of law enforcement and on environmental and economic matters. Hawke's Defence Minister, Kim Beazley, by then on the opposition benches, was furious at Australia ceding its 'intellectual leadership' in the region (Beazley 1997).

7 Jim Bolger quoted in Press Release: Parliament Building, Wellington New Zealand, 17 February 1997: transcript of the Prime Minister and the Prime Minister of New Zealand, Parliament of Australia. 
That 'intellectual leadership' passed to New Zealand's Helen Clark when she became prime minister in 1999, but she would make sure that the relationship with Australia was consultative. By 2000, more of the island states were having economic and political difficulties and the New Zealand government had come around to the Australian view that improved governance was a regional necessity. Despite the vast difference between their ideological outlooks, Clark and Howard were able to form a respectful, even friendly, working partnership on a range of regional issues. In a major departure from tradition, both leaders refrained from criticising each other openly, and in conversations with his major ally, the United States, Howard noted that the two governments were working well together in the region, attributing minor differences to the fact that the New Zealanders were 'soft Saxons, with a disposition to the centre-left and with fewer resources' (WikiLeaks 2006).

When 'minor differences' did occur, Clark was sometimes able to prevail, sometimes not. It was New Zealand who put the 'cooperative' into the Howard Government's regional doctrine of 'cooperative intervention', announced by Foreign Minister Alexander Downer in June 2003. When Australia suddenly decided that it was in its interests to abandon its policy of non-intervention in the Solomon Islands crisis in May 2003, it initially planned to undertake the operation unilaterally. This approach was in keeping with Howard's own realist foreign policy preferences and with those of his American counterpart at the time, President G. W. Bush. Helen Clark, who was an even more passionate liberal internationalist than most New Zealand political leaders, and chair of the Pacific Islands Forum at the time, negotiated hard with Howard and persuaded him that the intervention should have 'the approval of the Pacific Islands Forum and the involvement of as many island states as possible - not to mention the invitation of the host country' (Young 2006).

She was not so successful in trying to persuade Howard to emulate New Zealand's approach on Bougainville and take a more 'softly-softly' approach, with unarmed soldiers or police leading the intervention. Nor was she successful in persuading him that the Solomon Islands government should be closely engaged in the subsequent state strengthening process (Adams 2012).

Transforming the planned 'Australia/Solomon Islands bilateral initiative' (Trevett 2008) into the Regional Assistance Mission to the Solomon Islands (RAMSI) was not Helen Clark's first or last significant regional initiative. The Pacific Islands Forum Biketawa Declaration, under whose auspices she insisted RAMSI be undertaken, had itself been conceived and promoted by her government. In August 2000, following the ousting of elected governments in Fiji and Solomon Islands, New Zealand had organised the first meeting of Pacific Islands Forum foreign ministers. At that meeting, hosted by the Samoan Prime Minister in Apia, New Zealand's Foreign Minister, Phil Goff, had put forward 
a proposal that the forum build on its previous declarations on regional security and develop procedures and processes for dealing with similar situations. The Australian foreign minister did not contribute at all to the ensuing discussion (McCraw 2005, p. 220; Tavola 2014).

Helen Clark also initiated the Pacific Plan and the Eminent Persons Group review of the forum during her stint as chair from 2003-2004 (Grynberg 2013). Afterwards she continued to be active in regional affairs, acting as a valued broker between disagreeing member states, negotiating the continuation of RAMSI in 2006 and instigating a review of its performance, and then in 2008 hammering out agreement that Fiji should be suspended from the forum in the event that it did not meet a 2009 deadline for democratic elections. According to Samoa's then prime minister, Clark's negotiation skills were formidable and she could be relied on to find 'the right word to reflect the areas where compromise can be reached. She has that talent' (Trevett 2008).

Australia's 2003 about-turn on direct assistance to the Solomon Islands had marked a new phase of regional assertiveness by Canberra, which included bilateral capacity-building initiatives with Nauru and Papua New Guinea, and attempts to strengthen regionalism and enhance Australia's capacity to influence its direction. This new assertiveness had not been welcomed with unalloyed joy in Wellington, partly because some of the Howard Government's proposals such as 'pooled regional governance' would have cut across New Zealand's national interests, and partly because its approach was seen as inappropriately interventionist. Much of Helen Clark's regional diplomacy in the years after 2003 can be seen as an attempt by New Zealand to moderate Howard's new regional concerns and ambitions.

Unfortunately, New Zealand officials did not have the same tact or skill when it came to trade negotiations with the region, sorely testing relations with the forum secretariat and with island leaders. When the secretariat responded to forum declarations on trade liberalisation and the looming prospect of free trade negotiations with the European Union by putting forward plans for an islands-only free trade agreement at the end of the 1990s, New Zealand was initially unconcerned. But it did not take long before it was aligning itself with its furious trans-Tasman neighbour to demand inclusion and subject forum and regional trade officials to scorn and intimidation. One of the New Zealand academics contracted to draft alternative proposals for the Australia and New Zealand governments complained: 'The whole experience was stressful and demoralising for me, let alone for the Pacific Islands negotiators. There were times that I felt ashamed to be a New Zealander; I was just pleased that I was not an Australian' (cited in Kelsey 2004, p. 16). 
As with most matters Pacific, the New Zealand and Australian positions were not identical and in the end the agreed compromise, the PICTA-PACER Agreement (Pacific Island Countries Trade Agreement-Pacific Agreement on Closer Economic Relations), was closer to that taken by New Zealand. And when negotiations for PACER Plus got under way, New Zealand proved more willing to provide the island countries with some compensation in the form of temporary access visas for a limited number of unskilled workers. But the seasonal workers scheme was not incorporated into PACER Plus and island leaders were only too aware that it could be terminated at any time. Both the negotiations and the outcome of the whole regional free trade process tarnished New Zealand's reputation for being more diplomatic and sympathetic towards their island counterparts than Australia.

This was not the first time that New Zealand had upset its island counterparts. Its honeymoon years with the forum's island members had ended abruptly with the election victory of the National Party in 1975. Prime Minister Robert Muldoon was unarguably the most realist post-war prime minister that New Zealand has had, with an abrasive and inflexible character to boot. Although he attended all the forum meetings and enjoyed doing so, he was less committed to maintaining a cordial relationship with the island governments than his predecessors - or his successors. His first priority was maintaining good relations with the United States and France, and it was this that caused the first real friction between forum island members and Australia and New Zealand. As soon as he became prime minister, Muldoon had brought the first South Pacific Nuclear Weapons Free Zone campaign to a halt, now siding with its long-time Australian government opponents and arguing down island leaders, most notably Ratu Mara, who wanted to continue the process of gaining it international acceptance (Templeton 2006, pp. 301-5). During his term, Australia and New Zealand also made an unpopular attempt to gain the United States membership in the proposed Forum Fisheries Agency.

New Zealand's dispute with the United States in the mid-1980s and its departure from the ANZUS alliance over nuclear ship access had also been unpopular with a number of the forum's island members, in particular with Ratu Mara, who had by then become more sympathetic to the United States, having been feted at the White House by President Reagan. Few in the region would have noticed that efforts to restore relations between New Zealand and the United States had begun almost immediately on both sides of the Pacific or will have appreciated the extent to which New Zealand has since sought to engage the Americans in regional affairs.

Relations between the United States and New Zealand had thawed considerably by 2003, when Helen Clark openly criticised the Bush administration's invasion of Iraq as a breach of international law. Even this proved only a temporary 
irritant, with New Zealand keen enough to secure a free trade agreement that it was willing to demonstrate a strong commitment to the War on Terror in other areas, namely Afghanistan and the South Pacific, albeit in the name of liberal internationalism.

New Zealand sought to strengthen American interest in the relationship by engaging it more closely in regional affairs. It persuaded the Pacific Islands Forum Secretary General, Greg Urwin, to schedule a special session for United States Assistant Secretary of State for East Asian and Pacific Affairs, Christopher Hill, after the 2006 forum meeting in Nadi, and it was Hill who suggested to Howard that Helen Clark take charge of negotiations with the Prime Minister of the Solomon Islands, Manasseh Sogavare, over his demand that RAMSI be terminated (WikiLeaks 2006). Foreign Minister Winston Peters, who had established a very cordial relationship with the US Secretary of State, Condoleezza Rice, even persuaded her to visit the region and meet Pacific Island leaders, which she did in 2009. New Zealand's efforts to sell itself as having a unique understanding of, and role in, the island Pacific met with such success in Washington that President Bush spoke of relying on 'New Zealand's leadership, with US help, to help solve the problems - and Australian help as well'.

Australia had by this time been compelled to take a less assertive role in regional affairs, partly for diplomatic reasons and partly for practical ones. On the diplomatic front, the Howard Government had managed to alienate Melanesian leaders with the aggressive cross-border pursuit of the Solomon Islands attorney general, and on the practical front, Australia's focus had swung back to its priority area of security interest, Southeast Asia. Although the Australian and New Zealand governments had by now instituted six-monthly meetings to discuss regional matters, New Zealand was left to push forward on strengthening Pacific regionalism and to provide much of the counterterrorism training and support activity in the region (WikiLeaks 2006).

By the time that Helen Clark had been replaced as prime minister by the National Party's John Key and the new Obama administration began instituting its 'pivot to Asia', New Zealand had made itself sufficiently useful to the United States that it was possible to engage in open cooperation on regional and international matters. The new Secretary of State, Hillary Clinton, visited New Zealand in 2012 and went on to the Pacific Island Forum meeting in the Cook Islands, the first in her position to do so.

The Key Government has engaged in close practical regional cooperation with the United States (and China), changed its regional aid priorities, and adopted a more informal but less tactful approach to its dealings with island leaders, but has retained an interest in strengthening the existing regional architecture. It initiated a review of the Pacific Islands Forum Secretariat in 2012 and provided 
support to the Polynesian Leaders Group (PLG), formed in 2011 as a response to the activism of the Melanesian Spearhead Group. The Ministry of Foreign Affairs and Trade hosted meetings of the PLG in its Auckland offices in 2013 and then flew them all to the forum meeting in Majuro with John Key. The Ministry of Foreign Affairs and Trade again played host to the PLG in 2015.

China's increasing presence in the island Pacific and Fiji's establishment of the Pacific Islands Development Forum as a region-wide but island-only organisation have both been of concern to New Zealand - as they have to Australia. They were undoubtedly factors in the hasty restoration of ties with Fiji after its 2014 elections. When Fiji then insisted that the price of its return to the Pacific Islands Forum was the relegation of Australia and New Zealand to the status of development partners, New Zealand was quick to send ministers and officials to remind their island counterparts of Australia and New Zealand's contributions to their economies. Prime Minister Key was even less diplomatic in his public pronouncements than his Australian counterpart. What, he asked, would the forum do without Australian and New Zealand funding? 'Where would they get the money to do anything? And the answer is nowhere. None of them have that' (Radio New Zealand 2015).

New Zealand's public response to Bainimarama's demands, its position on free trade, and its support for improved governance in the island countries have given many observers the impression that when it comes to regional matters, 'you probably couldn't slide a pandanus leaf between Canberra and Wellington' (Honnor 2003). And it has been assumed that it is Australia that has called the tune, because of its size and its more insistent and assertive approach. But impressions can be misleading, as this brief examination has demonstrated. New Zealand has rarely completely agreed with Australia on regional issues and has often either provided the intellectual leadership or been successful in influencing policy in Canberra. This should come as no surprise. New Zealand's identification with the fortunes of the island Pacific predates the latter's emergence as a region of independent states, while Australia has no such intense or durable interest. Small powers with limited resources such as New Zealand have an added incentive to think creatively about the pursuit of their national interests.

It is often claimed by New Zealanders that while Australia works on the region, New Zealand works in it. But in recent decades, both have given the appearance of responding to the island countries' economic and political difficulties by pushing for greater regional activism and integration. Assuming this kind of managerial role in the region and adopting a public posture of complete solidarity with Australia entails costs as well as benefits for New Zealand. New Zealand should not forget that good relations with Pacific Island governments are fundamental to the successful implementation of its efforts to 
improve regional prosperity, stability, and resilience, and to its foreign policy identity and international credentials. Its leaders and officials once had the imagination, creativity and tact to work with Pacific Island governments on a form of regionalism that suited everyone. It would be great pity if New Zealand were to squander the considerable regional and international capital amassed during those years by appearing more interested in defending its own interests and ideas than in listening to and engaging with the rest of its Pacific Island family.

\section{References}

Adams, P., 2012, Former Head of NZAid, Suva, interview with author, 25 November.

Beazley, K., 1997, 'Ministerial Statement: 28th South Pacific Forum, Rarotonga, Cook Islands 17-19 September 1997', House Hansard, Thursday, 2 October 1997, Parliament of Australia, p. 9100.

Brown, P., 1997, 'Document Highlights Australia-NZ Tensions', Militant 61(31).

Cumberland, K.B., 1962, 'The Future of Polynesia', Journal of the Polynesian Society $71(4)$.

Doran, S., 2004, Australia and the Origins of the Pacific Islands Forum, Australia and the World: The Foreign Affairs and Trade Files, No. 1, Commonwealth of Australia, Canberra.

Fry, G., 1997, 'Framing the Islands: Knowledge and power in changing Australian images of 'the South Pacific', Contemporary Pacific 9(2), pp. 305-44.

Grynberg, R., 2013, 'The Pacific Plan and Other Failures: What can be learned?', Pacific Media Centre, 16 January. Available at: www.pmc.aut.ac.nz/articles/ pacific-plan-and-other-failures-what-can-be-learned.

Honnor, G., 2003 'Greg Urwin I Gutpela Man Long Dispela Wok', Club Troppo, 17 August. Available at: clubtroppo.com.au/2003/08/17/greg-urwin-igutpela-man-long-dispela-wok/.

Kelsey, J., 2004, 'Big Brothers Behaving Badly: The implications for the Pacific Islands of the Pacific Agreement on Closer Economic Relations (PACER)', Interim Report Commissioned by the Pacific Network on Globalisation. Available at: www.scoop.co.nz/stories/PO0404/S00030.htm.

Lal, B.V., (ed.) 2006, Fiji: Documents on the end of Empire, volume 10 series B, The Stationery Office, London. 
McCraw, D., 2005, 'New Zealand Foreign Policy Under the Clark Government: High tide of liberal internationalism?', Pacific Affairs 78(2).

McGibbon, I. (ed.), 1999, Unofficial Channels: Letters between Alister McIntosh and Foss Shanahan, George Laking, Frank Corner 1946-1966, Victoria University Press, Wellington, 1999.

Radio New Zealand, 2015, 'Bainimarama Mouthing off Over Forum — Key', 13 April. Available at: www.radionz.co.nz/international/pacific-news/271083/ bainimarama-mouthing-off-over-forum-key.

Tavola, K., 2014, Former Foreign Minister of Fiji, interview with author, Suva, 19 November

Templeton, M., 2006, Standing Upright Here: New Zealand in the nuclear age 1945-1990, Victoria University Press, Wellington.

Trevett, C., 2008, 'Old Hand Bridges Pacific Divide', New Zealand Herald, 23 August.

WikiLeaks, 1976, 'South Pacific Forum Nations Agree on Joint Action to Counter Soviet Ambitions in South Pacific', 1 July. Available at: wikileaks.org/plusd/ cables/1976WELLIN02889_b.html.

WikiLeaks, 2006, 'Pacific Islands Forum 2006, A/S Hill Underscores U.S. Engagement in Pacific', 13 November. Available at: wikileaks.org/plusd/ cables/06SUVA490_a.html.

Young, A., 2006, 'Riots highlight NZ presence', New Zealand Herald, 22 April. 
This text is taken from The New Pacific Diplomacy, edited by Greg Fry and Sandra Tarte, published 2015 by ANU Press, The Australian National University, Canberra, Australia. 